\title{
Effect of the Burrowing Activities of the Common Vole and the Mole on the Soil and Vegetation of the Biocenoses of Cultivated Fields ${ }^{1}$
}

\author{
Wanda GOSZCZYŃSKA \& Jacek GOSZCZYŃSKI ${ }^{2}$
}

\begin{abstract}
Goszczyńska W. \& Goszczyński J., 1977: Effect of the burrowing activities of the common vole and the mole on the soil and vegetation of the biocenoses of cultivated fields. Acta theriol., 22, 10: 181-190 [With 6 Tables \& 4 Figs.].

The burrowing activities of small mammals (common vole, mole) in the biocenoses of cultivated fields were evaluated and it was found that the soil from burrows of small rodents is more humid than control soil. Estimates were made of the weight, volume and area occupied by soil from molehills. It was found that molehills exert a stimulating effect on the development of plants in the immediate vicinity of molehills.

[Inst. Ėcol., Dept. Agroecol., 64-003 Turew, Poland].
\end{abstract}

\section{INTRODUCTION}

Studies on the effect of the common vole (Microtus arvalis $\mathrm{Pa} 11 \mathrm{as}$, 1779) and the mole (Talpa europaea Linnae u s, 1758) on formation of certain habitat elements were carried out from summer 1973 to the autumn of 1975 and covered the following problems: effect of the common vole on humidity relations in soil and the significance of the mole's burrowing activities in meadow habitats.

\section{STUDY AREA}

The studies were carried out at Turew $\left(52^{\circ} 04^{\prime} \mathrm{N}, 16^{\circ} 48^{\prime} \mathrm{E}\right)$ in the Leszno voivodship, in meadows and fields situated in the vicinity of the Agricultural Biology Station of the Institute of Ecology, Polish Academy of Sciences. The area is a plain, with great predominance of arable land $(80 \%)$. The sites preferred by voles are perennial plantations: meadows (which occupy about $11 \%$ of the whole area), lucerne and clover (jointly about 5\%). Voles also occur in overwintering corns and spring plantations, although in far smaller numbers (R y s k owski, Goszczynski \& Truszkowski, 1973). Estimates of the humidity of burrows dug

\footnotetext{
'Praca została wykonana w ramach problemu węzłowego 09.1.7., koordynowanego przez Instytut Ekologii PAN.

Present address: Inst. Kształtowania Środowiska, 02-078 Warszawa, Krzywickiego $\theta$.
} 
by $M$. arvalis were made in fields of alfalfa, oat stubbly field and in meadows. Studies on intensity of soil transport by moles and the effect of the ejected soil on vegetation were limited to meadow sites, although moles were also found to be present in wooded areas and shelterbelts. The meadows included in the studies are in intensive agricultural use ( $2-3$ hay harvests per year, cattle grazing). Fertilization is usually carried out in early spring using manure and mineral fertilizers, and the meadows are also rolled and harrowed. The plant species greatly predominating in meadows is Dactylis glomerata L., then other species occurring most often are Deschampsia caespitoza L., Lolium perenne L., Taraxacum officinale Web., Plantago maior L., P. media and P. lanceolata L., Potentilla argentea L., P. anserina $\mathrm{L}$., and $P$. repens $\mathrm{L}$., and Trifolium repens $\mathrm{L}$.

\section{STUDY METHODS}

\subsection{Humidity of the Burrows of Small Rodents}

Studies on differences in humidity between soil in the burrows of $M$. arvalis and soil of undisturbed structure were initiated in the summer of 1973. A total number of 668 samples were taken at various times of the year, 98 on alfalfa, 50 on stubblefield, and 520 on meadows. Soil was taken from the bottom of the burrow for determination of humidity. For purposes of comparison soil samples were simultaneously taken from an undisturbed profile at the same depth and at a distance of $100 \mathrm{~cm}$ from the burrow. Humidity was estimated by means of the drying method and presented in percentage of weight. Comparisons were made for successive dates.

\subsection{The Mole's Activities in a Meadow Habitat}

The amount of soil transport to the surface by moles was examined at weekly intervals on six trial plots chosen at random, each $400 \mathrm{~m}^{2}$ in area $(20 \times 20 \mathrm{~m})$, measuring each time the length, breadth and height of new mole-hills, in order to define by means of these measurements the area occupied by mole-hills and the volume of soil ejected by the moles. After making the measurements the soil from the molehills was scattered over the plot and lightly trampled, making it easier in this way to find new molehills during the next inspection. As the weight of molehills was not estimated on the plots, a series of molehills differing in volume was taken and dried at $105^{\circ} \mathrm{C}$. The relation obtained: $\log \mathrm{Y}=1.58+0.59 \log \mathrm{X}$, where: $Y$ - weight $(\mathrm{g})$, and $X$-volume $\left(\mathrm{cm}^{3}\right)$, was used to calculate the weight of molehills on the study plots.

Examination of the effect of molehills on vegetation was made in other parts of the meadows. Molehills were chosen at random, taking from 1-4 samples of plants near the molehill to determine their biomass, and from 1 to 4 control samples at a distance of 1 metre from the molehill. A sample consisted of plants enclosed in a circle $300 \mathrm{~cm}^{2}$ in area. The plants within the circle were cut, then weighed to determine fresh mass, then dried at $80^{\circ} \mathrm{C}$ to constant weight and weighed again. In 1974 from 60 to 75 samples from the edge of the molehill and from 60 to 75 control samples were taken in each series of measurements, for an average of about 30 molehills. In 1975 from 40 to 60 samples were taken from the edge of the molehill and the same number of control samples, for 38 molehills 26 days oid and 43 molehills 9 days old. 
In addition the effect of the molehills on soil temperature and humidity near the molehills was estimated. A diagram of the measurements made is given in Fig. 1.

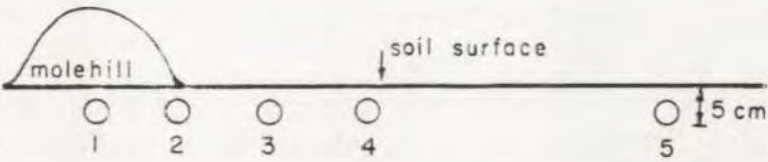

Fig. 1. Diagram of measurements of soil temperature and humidity at different distances from a molehil.

1 , centre; 2 , edge; $3,10 \mathrm{~cm}$ from edge; $4,20 \mathrm{~cm}$ from edge; $5,1 \mathrm{~m}$ from edge (standard).

\section{RESULTS AND DISCUSSION}

\subsection{Humidity of the Burrows of Small Rodents}

In 1973 samples for humidity were taken from alfalfa, a meadow and a field of oat stubble, but in 1974 from the meadow only. In 1973, with rainfall of $522 \mathrm{~mm}$ and low soil humidity, statistically significant differences were found between the humidity of control soil and soil from burrows in the alfalfa field and oat stubbly field (Table 1). Humidity of

Table 1

Differences in soil humidity in burrows of $M$. arvalis and in undisturbed soil (depth $0-30 \mathrm{~cm}$ ).

\begin{tabular}{lclrrrr}
\hline $\begin{array}{c}\text { Date of } \\
\text { measurement }\end{array}$ & $\begin{array}{c}\text { No. of } \\
\text { samples }\end{array}$ & Crop & $\begin{array}{c}\text { Soil humidity, \% } \\
\text { in burrow control }\end{array}$ & $\begin{array}{l}\text { Differ- } \\
\text { ences, \% }\end{array}$ & $P$ \\
\hline 28.VII.1973 & 18 & alfalfa & 12.75 & 11.37 & 12.1 & $0.05>P>0.02$ \\
31.VII.1973 & 30 & alfalfa & 12.17 & 11.06 & 10.0 & $0.5>P>0.2$ \\
22.VIII.1973 & 50 & stubble & 5.20 & 2.70 & 92.5 & $P<0.001$ \\
28.VIII.1973 & 50 & alfalfa & 2.33 & 1.60 & 45.6 & $P<0.001$ \\
30.VIII.1973 & 30 & meadow & 3.03 & 3.39 & 10.6 & $0.5>P>0.2$ \\
19.IV.1974 & 80 & meadow & 15.80 & 15.40 & 2.6 & $0.2>P>0.1$ \\
20.V.1974 & 80 & meadow & 9.30 & 9.20 & 1.1 & $0.5>P>0.2$ \\
30.VII.1974 & 80 & meaciow & 31.50 & 30.67 & 2.6 & $0.1>P>0.05$ \\
23.VIII.1974 & 80 & meadow & 17.25 & 16.90 & 1.8 & $0.1>P>0.05$ \\
24.X.1974 & 80 & meadow & 26.60 & 25.24 & 3.6 & $0.5>P>0.2$ \\
4.XII.1974 & 90 & meadow & 39.84 & 38.85 & 2.6 & $0.5>P>0.2$
\end{tabular}

the burrows was lower in the meadow than humidity of control soil, but differences were not statistically significant.

In 1974 , with very high rainfall $(706 \mathrm{~mm})$, greater soil humidity was found in the burrows than had been the case the previous year. Although differences in humidity were slight (in different series of measurements the soil from burrows was $1-3.6 \%$ more humid than the control soil), they were recorded throughout the whole study period during which 
measurements were made (Table 1). In addition it was found that the soil at the entrance to the burrow was slightly dryer than undisturbed soil. With increase of depth to $10 \mathrm{~cm}$, difference in humidity between samples from the burrow and control samples continued to increase, although these differences decrease with further increasing depth and at depths over $20 \mathrm{~cm}$ disappear (Fig. 2).

It is possible that the interval of time since the previous rainfall may considerably effect differences in humidity between soil from burrows and standard soil. The samples taken on lucerne showed that differences in humidity in favour of burrows are: 1 day after rainfall $-1.5^{0} \% ; 4$ days after rainfall $-1.1 \% ; 20$ days after rainfall $-0.8 \%$.

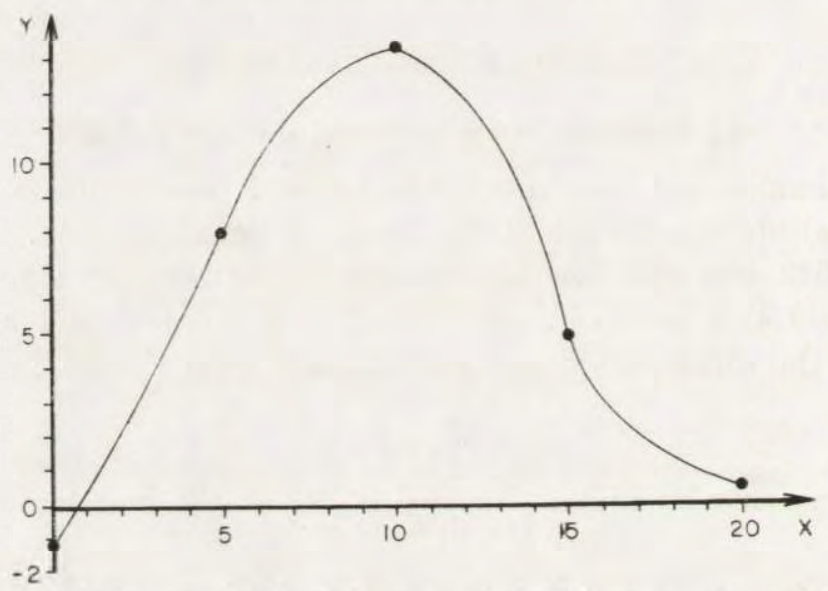

Fig. 2. Relation between depth of burrow and differences in soil humidity. $X$, depth $(\mathrm{cm}) ; \mathrm{Y}$, difference between humidity in burrow and standard sample, per cent.

It would appear that the burrows of $M$. arvalis form a water store, especially as increased soil humidity in comparison with the standard was observed even at a distance of up to $20 \mathrm{~cm}$ from the burrow. The average humidity obtained from the series of measurements made on 3 th April 1973 for standard soil on meadows was $32.9 \%$, and humidity of samples taken from the neighbourhood of burrows $(5,10,15,20 \mathrm{~cm}$ sideways from the burrow) $-35.2^{\%} \%(0.1>P>0.05)$. Water retention in the surface layers on soil may be considerable during periods of mass occurence of voles, when their density in some crops is as high as 2000 individuals per 1 ha (Ryszkowski et al. 1973), and the number of burrows can be as great as tens of thousand per 1 ha (B a shenina, 1962). It may be that losses of vegetation due to mass occurence of voles may to some degree be recompensed if such: it takes place in a dry year and the plants are able to make use of the water accumulated round the burrows. 


\subsection{The Mole's Activities in a Meadow Habitat}

The observations carried out throughout a whole year made it possible to define the area occupied by a molehill and the volume and weight of ejected soil in successive months per 1 ha. It was found that the greatest values of these parameters were encountered during the period October-

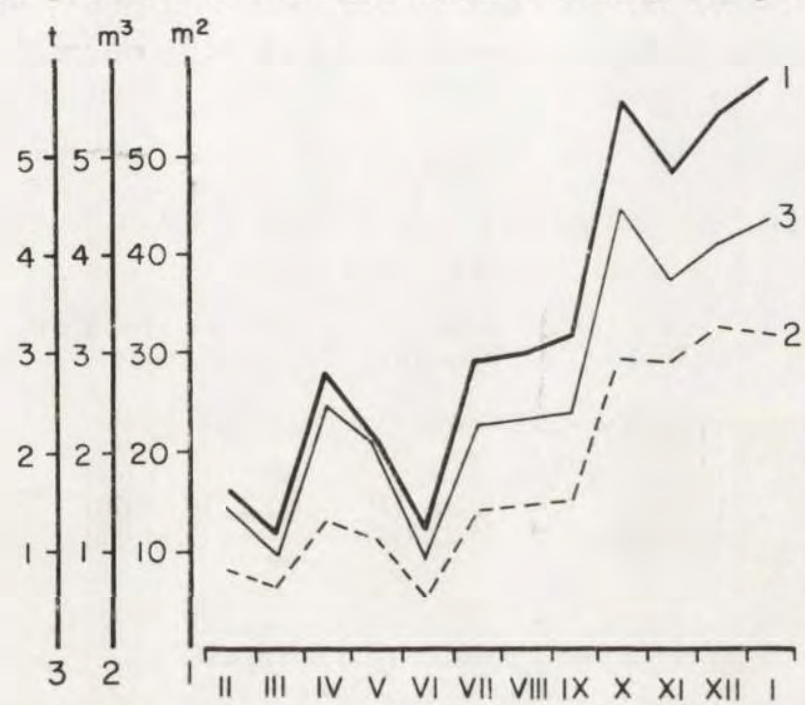

Fig. 3. Variations in area occupied by molehills and volume and weight of soil thrown up by moles per 1 ha of meadow.

1, area of molehills; 2, volume of soil from molehills; 3 , weight of dry soil from molehills.

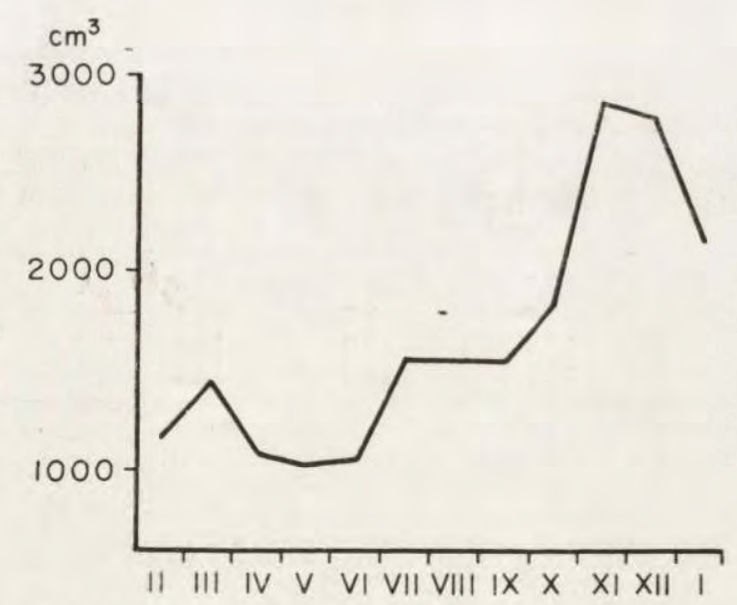

Fig. 4. Size of average molehill in successive months.

January (Fig. 3). Popov (1960) observed similar increase in moles activity during the winter months. At the same time, i.e. autumn and winter months, moles formed molehills of greater volume (Fig. 4). 
During the course of a year moles throw up $21 \mathrm{~m}^{3}$ of soil/ha of meadow, which corresponds to 32 tons/ha. The molehills formed during one year occupied $398 \mathrm{~m}^{2}$. The results obtained for weight and volume of ejected soil are greater than those given by $\mathrm{Ab}$ a t u r ov (1968) for coniferous forests, and similar to the results given by Grulich (1959) for meadows in Czechoslovakia. This last author estimated the weight of ejected soil as 50 tons/ha/year, but the estimate was made of fresh soil, whereas that given in the present paper refers to the weight of dry soil. The

Table 2

Soil humidity in a molehill and its vicinity (depth $5 \mathrm{~cm}$ ), Turew 1974. Number of samples given in brackets.

\begin{tabular}{clccc}
\hline $\begin{array}{c}\text { Date of } \\
\text { measurement }\end{array}$ & $\begin{array}{l}\text { Centre of } \\
\text { molehill }\end{array}$ & $\begin{array}{c}\text { Edge of } \\
\text { molehill }\end{array}$ & $\begin{array}{c}\text { Distance 10-15 cm } \\
\text { from edge }\end{array}$ & Control \\
\hline 19.III. & $12.90(1)$ & $12.81(4)$ & $17.55(8)$ & $15.44(16)$ \\
22.IV. & $45.90(9)$ & $45.50(9)$ & $48.68(9)$ & $45.82(20)$ \\
2.V. & $16.30(17)$ & $15.22(32)$ & $15.24(68)$ & $14.99(68)$ \\
2.VII. & $15.31(4)$ & $15.22(70)$ & $14.98(38)$ \\
15.VIII. & $15.40(10)$ & $15.22(40)$ & $15.16(55)$ & $16.10(38)$ \\
\hline
\end{tabular}

volume of ejected earth may sometimes (in periods of mass occurence of moles) be as great as $150 \mathrm{~m}^{3} / \mathrm{ha}$ ( $\mathrm{J}$ on c a, 1964).

Although 5 series of samples were taken for determining soil humidity, the vicinity of molehills was not found to differ significantly in respect of humidity in from any of the series from the control (Table 2). It was

Table 3

Soil temperature $\left({ }^{\circ} \mathrm{C}\right)$ at depth of $5 \mathrm{~cm}$ near molehill. Measurements of temperature made at hourly intervals over 24 hour period.

\begin{tabular}{|c|c|c|c|c|}
\hline \multirow{2}{*}{$\begin{array}{l}\text { Date of } \\
\text { measurements }\end{array}$} & \multicolumn{4}{|c|}{ Site of temperature measurement } \\
\hline & $\begin{array}{c}\text { Centre of } \\
\text { molehill }\end{array}$ & $\begin{array}{l}\text { Edge of } \\
\text { molehill }\end{array}$ & $\begin{array}{l}10-15 \mathrm{~cm} \\
\text { from edge }\end{array}$ & $\begin{array}{l}1 \mathrm{~m} \text { from edge, } \\
\text { control }\end{array}$ \\
\hline 22.IV.1974 & 7.7 & 7.7 & 7.5 & 7.6 \\
\hline 23.IV.1974 & 7.2 & 7.2 & 7.1 & 7.2 \\
\hline 20.V.1974 & 17.8 & 13.8 & 13.8 & 14.2 \\
\hline 15.VII.1974 & 20.4 & 18.5 & 18.3 & 18.9 \\
\hline
\end{tabular}

only in the series of March measurements that the soil from the molehill and its edge was dryer than the control $(0.05>P>0.02)$, and soil from a distance of $15 \mathrm{~cm}$ from the edge more humid than the control $(0.1>P>$ $0.05)$. Differences in the other series were not statistically significant.

Molehills exert a marked influence on the soil temperature in their vicinity (Table 3), but reduction in temperature near the molehill is a secondary effect, due to the fact that plants near a molehill are taller 
and limit heating of the soil. This mechanism is confirmed by the fact that differences in soil temperature near the molehill and at a standard distance become smaller after the plants are cut down. In the series of temperature measurements made during the last 10 days of May 1974, differences between the control temperature and temperature at a distance of $15 \mathrm{~cm}$ from the molehill was $0.24^{\circ} \mathrm{C}$, but after the plants had been cut down was only $0.03^{\circ} \mathrm{C}$. In the series of July measurements the differences were as follows: $0.70^{\circ} \mathrm{C}$ with plant cover, and $0.35^{\circ} \mathrm{C}$ after cutting down the plants. In both series these differences were significantly different $(P<0.001$ and $0.01>P>0.001)$. Temperature in the interior of a molehill is usualy higher than the control, particularly during the late spring and summer periods, but this depends on insolation and rainfall, since in April 1974 when there were passing showers during the measurement period, temperature inside the molehill did not differ from the control temperature (Table 4).

Table 4

Plant biomass near molehill and at distance of $1 \mathrm{~m}$ from molehill. Area of sample was $300 \mathrm{~cm}^{2}$. Approx. 30 molehills were examined in each series of measurements.

\begin{tabular}{|c|c|c|c|c|}
\hline $\begin{array}{l}\text { Date of } \\
\text { estimate }\end{array}$ & $\begin{array}{r}\text { No. of } \\
\text { samples }\end{array}$ & Parameters & $\begin{array}{l}\text { Fresh } \\
\text { mass in } \mathrm{g}\end{array}$ & $\begin{array}{l}\text { Dry mass } \\
\text { in } \mathrm{g}\end{array}$ \\
\hline 20.V.1974 & $\begin{array}{l}62 \\
63\end{array}$ & $\begin{array}{l}\text { edge of molehill } \\
1 \mathrm{~m} \text { from molehill } \\
\text { difference in } \% \\
\text { significance of } \\
\text { differences to }\end{array}$ & $\begin{array}{c}64.1 \\
51.0 \\
25.7 \\
2.90 \\
0.01>P>0.001\end{array}$ & $\overline{-}$ \\
\hline 28.V.1974 & $\begin{array}{l}74 \\
74\end{array}$ & $\begin{array}{l}\text { edge of molehill } \\
1 \mathrm{~m} \text { from molehill } \\
\text { difference in } \% \\
\text { significance of } \\
\text { aifference to }\end{array}$ & $\begin{array}{c}66.3 \\
52.9 \\
25.2 \\
2.74 \\
0.01>P>0.001\end{array}$ & $\begin{aligned} 13.24 \\
10.44 \\
26.80 \\
3.14 \\
0.01>P>0.001\end{aligned}$ \\
\hline 29.VII.1974 & $\begin{array}{l}76 \\
76\end{array}$ & $\begin{array}{l}\text { edge of molehill } \\
1 \mathrm{~m} \text { from molehill } \\
\text { difference in } \% \\
\text { significance of } \\
\text { difference to }\end{array}$ & $\begin{array}{c}29.0 \\
23.6 \\
22.8 \\
2.76 \\
0.01>P>0.001\end{array}$ & $\begin{array}{r}7.30 \\
6.25 \\
16.80 \\
2.28 \\
0.02>P>0.01\end{array}$ \\
\hline
\end{tabular}

No significant differences were found between acidity of soil taken from molehills and that of control soil. In the first series of measurements made on soil from 50 old molehills soil pH was 7.0 (control 6.9), and in the second series taken from a different meadow soil $\mathrm{pH}$ for 25 newly formed molehills was 6.4 (control 6.4).

Estimates of plant biomass taken from the vicinity of a molehill and at a distance of $1 \mathrm{~m}$ from it (control) indicate that in the vicinity of a molehill plants develop to a greater extent. In 1974 samples were taken 
three times on different meadows and in all cases plant biomass near molehills was on an average $20-25^{\circ} \%$ greater than the biomass of control plants (Table 4). It was also found that the size of the molehill affected the height and biomass of vegetation near molehills, but this influence aepends on the time at which the molehill had been formed (Table 5). Near »old " molehills ( 26 days from time of their formation) vegetation was found to be more luxuriant, the larger the molehill the greater being the biomass of the plants, whereas plant biomass near "new " molehills (9 days from their formation) does not differ from control biomass (Table 5).

In places in which molehills once formed may persist for years, the burrowing activities of moles is favourable to plant succession. For

Table 5

Effect of size and age (days) of molehill on plant biomass near its edge. Samples taken from within circle $300 \mathrm{~cm}^{2}$ in area.

\begin{tabular}{|c|c|c|c|c|c|c|c|}
\hline \multirow{2}{*}{$\begin{array}{l}\text { Diameter of } \\
\text { molehill }(\mathrm{cm})\end{array}$} & \multicolumn{3}{|c|}{26 days } & \multicolumn{4}{|c|}{9 days } \\
\hline & $\begin{array}{c}\text { No. of } \\
\text { molehills }\end{array}$ & $\begin{array}{l}\text { Fresh } \\
\text { mass, g }\end{array}$ & $\begin{array}{l}\text { Dry } \\
\text { mass, } g\end{array}$ & & $\begin{array}{l}\text { No. of } \\
\text { molehills }\end{array}$ & $\begin{array}{l}\text { Fresh } \\
\text { maśs, g }\end{array}$ & $\begin{array}{c}\text { Dry } \\
\text { mass, g }\end{array}$ \\
\hline 25 & 2 & 85.5 & 15.6 & & 2 & 52.5 & 8.3 \\
\hline 20 & 6 & 124.2 & 20.5 & & 13 & 72.2 & 13.0 \\
\hline 25 & 12 & 120.0 & 20.6 & & 12 & 60.7 & 11.8 \\
\hline 30 & 6 & 151.8 & 26.7 & s & 11 & 73.3 & 13.5 \\
\hline 35 & 7 & 159.3 & 30.7 & & 5 & 73.0 & 12.5 \\
\hline 40 & 4 & 152.7 & 26.3 & & & & \\
\hline 45 & 1 & 242.4 & 39.7 & & & & \\
\hline Avg. molehill & 38 & 138.4 & 24.4 & & 43 & 67.3 & 12.2 \\
\hline Control & 38 & 74.5 & 13.4 & & 43 & 70.9 & 12.8 \\
\hline
\end{tabular}

instance in forests molehills are first of all overgrown by moss, then vegetatively reproducing plants and tree lichen ( $\mathrm{J} \mathrm{a} \mathrm{k} \mathrm{u} \mathrm{š} \mathrm{ev,} \mathrm{1941;}$ Tihomirova, 1967b).

In the study area, however, molehills are destroyed every $2-3$ month by rolling or other agriculture activities. Intensive grazing by cattle also contributes to rapid destruction of molehills. Under such circumstances differences in the biomass of plants near molehills and at a distance from them cannot be explained by the difference in species composition. Tihomirova (1967a) has earlier drawn attention to the fact that the species composition of plants near recently formed molehills does not differ from that of neighbouring plant cover.

Measurements of the height of grass near molehills showed that the plants growing there are significantly higher than grasses beyond the effect of the molehill (Table 6). It was also found that in the case of large molehills $30 \mathrm{~cm}$ in diameter grass is on an average $20 \%$ higher 
than grass growing near small molehills $10 \mathrm{~cm}$ in diameter $(0.01>P>0.001$ for $\mathrm{N}=828$ ).

It is extremely difficult to determine the causes of the stronger growth of plants in the immediate vicinity of molehills. It may be that physicochemical conditions exert a stimulating effect, e.g. better insolation of plants near the edge of a molehill or more intensive aeration of soil. Olszewski \& Skoczen (1969) emphasized the fact that fresh molehills are well aerated. Although no differences were found in this study in soil humidity near a molehill and in control soil it would seem that the flow of rainwater over the surface of the molehill must increase

Table 6

Differences in height of grass near a molehill and $1 \mathrm{~m}$ from it. Number of measurements given in brackets.

\begin{tabular}{|c|c|c|c|}
\hline \multirow{2}{*}{$\begin{array}{c}\text { Date of } \\
\text { measurement }\end{array}$} & \multicolumn{2}{|c|}{ Height of grass in $\mathrm{cm}$} & \multirow{2}{*}{$\begin{array}{l}\text { Significance of } \\
\text { differences } t^{\circ}\end{array}$} \\
\hline & Near molehill & $1 \mathrm{~m}$ from molehill & \\
\hline 30.IV.1974 & $15(110)$ & $11(66)$ & $\begin{array}{l}6.66 \\
P<0.001\end{array}$ \\
\hline 30.IV.1974 & $13(44)$ & $11(66)$ & $\begin{array}{l}3.07 \\
0.01>P>0.001\end{array}$ \\
\hline 30.IV.1974 & $15(66)$ & $11(66)$ & $\begin{array}{l}\text { 6. } \\
P<0.001\end{array}$ \\
\hline 11.V.1974 & $23(190)$ & $20(170)$ & $\begin{aligned} & 3.22 \\
0.01>P>0.001 & \end{aligned}$ \\
\hline 13.V.1974 & $22(281)$ & $18(289)$ & $\begin{array}{l}6.60 \\
P<0.001\end{array}$ \\
\hline
\end{tabular}

soil humidity in its vicinity. It is probable that the wide dispersion of data makes it impossible to record this phenomenon in measurements. It is also possible that the chemical compounds (chiefly $\mathrm{Fe}, \mathrm{Mg}, \mathrm{Al}$ ) carried out by moles from the deeper horizons of the soil profile exert a stimulating effect. According to A b a turov (1972) contents of these substances in the soil from molehills is greater than their concentration in horizon $A_{1}$ of the soil profile.

Acknowledgements: The authors wish to express their gratitude to C. K ukie 1ska. M. Sc., of the Department of Agroecology of the Institute of Ecology. Polish Academy of Sciences, at Turew and J. Kotowska of the Institute of Ecology, Polish Academy of Sciences, at Dziekanow Leśny for identifying the species of plants occurring in meadows in the Turew district.

\section{REFERENCES}

1. A baturov B. D., 1968: Vlijanije rojuščej dejatelnosti krota (Talpa europea L.) na počvennyj pokrov i rasitielnost' $\mathrm{v}$ širokolistvienno-elevom lesu. Pedobiologia, 8, 2: $239-264$. 
2. A baturov B. D., 1972: The role of burrowing animals in the transport of mineral substances in the soil. Pedobiologia, 12, 4: 261-266.

3. B a shenina N. V., 1962: Ekologia obyknoviennoj polevki i nekotorye čerty ee geografičeskoj izmenčivosti. Izd. Moskov. Univ.: 1-310. Moskva.

4. Grulich I., 1959: Význam ryci činnosti krtka obecnèho (Talpa europea) v CSSR. Práce Brnénskě základny CSAV, 31, 3: 157-212.

5. J a ku šev M. D., 1941: K voprosu o roli počviennoj fauny v smene rastitelnovo pokrova na suhodolnom lugu. Počvoviedenie, 5: 81-92.

6. Jońca E., 1964: Wpływ gryzoni i kretów na erozję gleb na Pogórzu Walbrzyskim (Sudety Srodkowe). Czasop. Geograf., 35, 1: 61-72.

7. Olszewski J. \& Skoczen S., 1965: The airing of burrows of the mole Talpa europea Linn a us 1758. Acta theriol., 10, 11: 181-193.

8. Popov V. A., 1960: Mlekopitajuščije Volžsko-kamskogo kraja. Izd. Akademii Nauk SSSR: $1-468$. Kazan.

9. Ryszkowski L., Goszczyński J. \& Truszkowski J., 1973: Trophic relationships of the common vole in cultivated fields. Acta theriol., 18, 7: $125-165$.

10. Tihomirova L. G., 1967a: Zakonomernosti formirovanija mohovyh sinuzij na ziemljanyh vybrosah krota $\mathrm{v}$ širokolistviennyh lesah Podmoskovija, Lesovedenije, $5: 55-66$.

11. Tihomirova L. G., 1967b: O vlijanii rojuščej dejatelnosti krota na rostitelnost lugov Moskovoj oblasti. Sb. „Struktura i funkcjonalno-biogeocenotičeskaja rol životnovo nasielenija suši«: 97-99. Moskva.

Accepted, November 12, 1976.

Wanda GOSZCZYÑSKA i Jacek GOSZCZYÑSKI

\section{WPEYW DZIAEALNOSCI RYJACEJ NORNIKA ZWYCZAJNEGO I KRETA NA GLEBE I ROSLINNOSC AGROCENOZ}

\section{Streszczenie}

Prowadzono oceny działalności ryjącej kretów i norników na polach i łąkach w okolicach Turwi. Stwierdzono, że gleba pochodząca z nor i korytarzy $M$. arvalis jest wilgotniejsza od gleby kontrolnej (Tabela 1). Największe różnice wilgotności między glebą $z$ nor a glebą kontrolną znaleziono na głębokości $10 \mathrm{~cm}$ (Ryc. 2).

Krety na łąkach wyrzucają w ciągu roku ok. $21 \mathrm{~m}^{3}$ gleby/ha co odpowiada ok. 32 tonom/ha (Ryc. 3). Maksimum aktywności ryjącej kretów przypada na okres jesień - zima (Ryc. 3, 4).

Produkcja roślinna w najbliższym sąsiedztwie kretowisk jest wyższa przeciętnie o $25 \%$ od produkcji roślinnej na terenach kontrolnych (Tabela 4). Na biomasę roślinności wokół kopca wpływa wiek kretowiska i jego wielkość (Tabela 5). Wyższa roślinność przy kretowiskach (Tabela 6), ogranicza nagrzewanie gleby (Tabela 3). Nie znaleziono różnic $w$ kwasowości gleby pochodzącej $z$ kretowisk i gleby kontrolnej. 